\title{
Selected Issues Concerning Public Tasks of The COMMUNes In Poland AND Germany
}

\author{
BARBARA ZYZDA*
}

\section{INTRODUCTION}

The Republic of Poland is an example of a unitary decentralized state with a characteristic inner unity and well-developed structures of territorial self-government ${ }^{1}$. The unitary system adopted by the country is a consequence of the homogenous character of Polish society in terms of nationality, culture and religion ${ }^{2}$. Public governance in Poland operates on the basic principle of decentralization. This is literally expressed in art 15 of the Constitution of the Republic of Poland of April 2, 1997 which claims that The territorial system of the Republic of Poland shall ensure the decentralization of public power, while art 16 of the Constitution affirms that Local government shall participate in the exercise of public power. The substantial part of public duties which local government is empowered to discharge by statute shall be done in its own name and under its own responsibility ${ }^{3}$. The most significant legal act regulating the institutional and legal situation of the commune in Poland is the Act of March 8, 1990 on commune territorial self-government ${ }^{4}$.

The Federal Republic of Germany is a federal political order. The country comprises member units known as federal states or Länder (16 federal states including 3 cities are awarded the status of Land: Brema (with Bremerhaven) Hamburg and Berlin) which individually enjoy a high degree of autonomy ${ }^{5}$. Germany has a four-tier territorial structure - the federation, Länder, i.e. federal states, counties and local administration units communes and municipalities, while the territorial self-government operates on two tiers - communes and municipalities and counties (except for

DOI: $10.1515 /$ wrlae-2015-0048

* PhD candidate in Law, University of Wrocław, Faculty of Law, Administration and Economics; barbara.zyzda@uwr.edu.pl

${ }^{1}$ Paweł Machalski, Europa samorzadna. Samorzad terytorialny $w$ wybranych państwach Unii Europejskiej (Wydawnictwo Adam Marszałek 2015) 38.

2 Piotr Winczorek, Komentarz do Konstytucji Rzeczypospolitej Polskiej z dnia 2 kwietnia 1997 r. (Liber 2000) 15.

${ }^{3}$ The Constitution of the Republic of Poland of 2 April 1997 Dziennik Ustaw - Official Journal of Laws of the Republic of Poland (hereinafter: Dz. U.) 1997 No 78, item 483, < http://www.sejm.gov.pl/prawo/konst/angielski/konse.htm > accessed 15 December 2017.

${ }^{4}$ Dz. U. 2016, No 446, item 1579.

${ }^{5}$ Machalski (n 2) 39. 
Bavaria where an additional territorial unit (Bezirk) is included $)^{6}$. It should be noted that there are a few exceptions where the administrative structure in the federal states is a two tiers, e.g. Berlin is subdivided into districts and neighbourhoods (Ortsteile).

According to The Basic Law of the Federal Republic of Germany, the Länder shall have the right to legislate insofar as this Basic Law does not confer legislative power on the Federation. The division of authority between the federal states and the Länder shall be governed by the provisions of this Basic Law concerning exclusive and concurrent legislative powers ${ }^{7}$. In the process of developing the structure of territorial self-government each Land individually followed the organisational scheme of its choice. The systems are anchored in four historical models: the south German system of councils, the system of mayors, the system of magistrates and the north German system of local councils .

Despite the fact that the self-government structures in Poland and Germany significantly differ, the commune, as a unit delivering public tasks on a large scale, plays an equally essential role in both countries.

\section{The Legal and Institutional Position of the Commune in POLAND AND GERMANY}

It should be noted that, as an element of territorial self-government, the commune in Poland does not belong to the structure of national government ${ }^{9}$. However, the commune and the state must not be juxtaposed. In contrast, in Germany the communes belong to the federal states level. The source of the power of the territorial self-government and its legitimacy finds its expression in the will of the state and it is the democratic state that, by law, defines the wide scope of the autonomy and independence claimed by the territorial self-government ${ }^{10}$.

This autonomy of Polish and German communes in particular manifests itself in the status of a legal person which enables them to enter into legal relationships with public authorities, hold and manage their own assets, participate in economic turnover and incur liabilities ${ }^{11}$. The fundamental pillars on which this autonomy rests are the commune's power to make local laws, its organisational and personal competencies and a financial and taxation control.

The word "commune" would originally refer to a community of a national character. Its existence was based on the natural law of

\footnotetext{
${ }^{6}$ ibid 90.

${ }^{7}$ Rafał Stasikowski, Gwarancje samorzadności gminnej w systemie prawnym Republiki Federalnej Niemiec i Rzeczypospolitej Polskiej (Oficyna Wydawnicza Branta 2005) 22.

8 ibid 26.

9 Zygmunt Niewiadomski, 'Kierunki rozwoju samorządu terytorialnego' 1991 (1-2) Samorząd Terytorialny 83.

${ }^{10}$ Renata Kusiak-Winter, Wspótpraca transgraniczna gmin Polski i Niemiec. Studium administracyjnoprawne (Prawnicza i Ekonomiczna Biblioteka Cyfrowa 2011) 99.

${ }^{11}$ Zbigniew Leoński, Samorząd terytorialny w RP (C.H. Beck 2010) 8.
} 
communities to decide about their own affairs. During the interwar period, such an approach was contested and certain authoritarian institutional changes were introduced which led to the abolishing of the separation of powers in the state ${ }^{12}$. In Poland, the commune, as a unit of territorial selfgovernment, was reinstated in 1990. The breakthrough in the process of shaping this administrative unit in Poland took place on January 1, 1999 on enacting the Commune Self-Government Act of July 24, 1998, which introduced the fundamental three-level territorial division of the state ${ }^{13}$. Accordingly, a new system of three-tier territory division into gmina (commune), powiat (county) and województwo (voivodship) was adopted.

The term of commune was defined in the aforementioned act on territorial self-government, where the legislator characterized the commune as a corporate body personally formed by a community of residents. W. Kisiel also emphasizes the origin of commune, its democratic internal organization and its purpose which is to constitute an essential part of the public administration at the local level and exercise its competences within this framework ${ }^{14}$.

The Constitution of the Republic of Poland states that the commune is the basic unit of local government. The legislator makes a presupposition with regard to the competences of this unit by saying that The commune shall perform all tasks of local government not reserved to other units of local government ${ }^{15}$.

In Poland, the commune is endowed with a legal personality, which means that it has not only a public and legal subjectivity but also that it is warranted the autonomy of operation. There are two types of communes rural and urban. The distinction has a formal character and relates to the names of commune bodies - commune council and city council ${ }^{16}$.

Article 169 of the Constitution of the Republic of Poland provides for the traditional division of the bodies of territorial self-government into statutory and executive. The duality of the commune bodies is also reflected by the Commune Act where the council is identified as the decision making body (art $18 \mathrm{sec} 1$ ), while the voyt (mayor or president) acts as the executive body (art $26 \sec 1)^{17}$. The commune council is appointed in universal, equal, direct and secret elections. The council acts for the commune as its statutory and controlling body. It decides on its internal organization by passing the statute of the commune. The commune council sits in sessions and while in session it may set up committees. Like German committees, they have a subsidiary rather than mandatory role ${ }^{18}$.

The single-member executive body of the commune - voyt, mayor or president - is elected on the basis of universal, free, equal, direct and

\footnotetext{
12 Jan Boć, Prawo administracyjne (Kolonia Limited 2010) 184.

${ }^{13}$ Dz. U. 1998, No 96, item 603.

${ }^{14}$ Wiesław Kisiel, 'Wstęp' in Paweł Chmielnicki (ed), 'Ustawa o samorządzie gminnym. Komentarz' (LexisNexis 2010) 22.

${ }^{15}$ Bogdan Dolnicki, Samorzad terytorialny (Wolters Kluwer SA 2016) 77.

${ }^{16}$ ibid 94.

${ }^{17}$ Renata Kusiak, 'Pozycja gminy w strukturze państwa polskiego i niemieckiego', Acta Universitatis Wratislaviensis No 1900, Prawo CCLIII, 76.

${ }^{18}$ Dolnicki (n 16) 96.
} 
secret suffrage ${ }^{19}$. This function is responsible for the enforcement of the council's resolutions and its external representation. A voyt, mayor or president performs his or her duties assisted and supported by the commune office.

It is worth remarking that the subject of each territorial selfgovernment unit is the community that lives in a commune, which means that the inhabitants are not only Polish citizens but also foreigners granted permanent residence in the area of that commune ${ }^{20}$.

A German commune is a territorial corporation of citizens. Its autonomy is based on administrative and territorial autonomy, organizational competence, local legislative power, autonomy in the scope of the relationships with the territorial self-government, financial autonomy and autonomy in the scope of economic development and urban planning ${ }^{21}$. It must be emphasized that each of the aforementioned expressions of autonomy must conform to domestic law.

In Germany, communes are part of the Land administration and according to the scope of their competence they act autonomously in dealing with, and assuming responsibility for, all matters regarding local communities $^{22}$. This rule is made explicit in the Constitution of the Federal Republic of Germany of May 23, 1949, where art 28 sec 2 stipulates that Municipalities must be guaranteed the right to regulate all local affairs on their own responsibility, within the limits prescribed by the laws. Within the limits of their functions designated by a law, associations of municipalities shall also have the right of self-government according to the laws. The guarantee of self-government shall extend to the bases of financial autonomy ${ }^{23}$.

Endowed with legal personality, the commune in Germany constitutes the self-government of public administration. Nonetheless, it is subordinate legislation (statutory instruments/orders, rules, regulations) that determines the system and the tasks of the commune in detail. It is important to bear in mind that only a few problems have found harmonised solutions across the whole German federation. The most important one is the commune's capacity to elect its representative collective body (with names differing from Land to Land i.a. commune council, city council, commune representative) to exercise the legislative power within its jurisdiction to the extent that such powers are not reserved for other bodies.

\footnotetext{
${ }^{19}$ Hubert Izdebski, Samorząd terytorialny. Podstawy ustroju i działalności (LexisNexis 2014) 252.

20 Jerzy Korczak, Piotr Lisowski, Adam Ostapski, Ustrój samorząu terytorialnego. Materiaty dydaktyczne (Prawnicza i Ekonomiczna Biblioteka Cyfrowa 2015) 55.

21 Jerzy Korczak, 'W Niemczech' in Jan Jeżewski (ed), Samorząd terytorialny $i$ administracja $w$ wybranych krajach. Gmina $w$ państwach Europy Zachodniej (Wydawnictwo Uniwersytetu Wrocławskiego 1999) 273.

22 Marcin Miemiec, Gmina w systemie administracji publicznej Republiki Federalnej Niemiec (Kolonia Limited 2007) 40.

${ }^{23}$ Basic Law for the Federal Republic of Germany of 23 May 1949, Bundesgesetzblatt (BGB1) I, 1949.

$<$ https://www.bundestag.de/blob/284870/ce0d03414872b427e57fccb703634dcd/basic law -data.pdf $>$ accessed 21 December 2016.
} 
The powers and responsibilities of the commune council include passing local laws, carrying out commune territorial transformations, determining rates of public levies or tariffs and controls ${ }^{24}$. Due to a collective and session-based mode of operation followed by the commune, these rights are largely implemented by the council's committees which play both advisory and decision-making roles ${ }^{25}$.

The bodies of the German commune are elected by universal, free, equal and secret suffrage ${ }^{26}$. A commune resident is, in accordance to the German legislation, anyone who has his or her place of residence there. The passive voting right and the active voting right are enjoyed only by those residents of communes who hold either German citizenship or the citizenship of another EU member state and have lived as residents of the commune for at least 3 months (or, in some Länder - 6 months) ${ }^{27}$.

The executive body of the German commune takes either the monocratic form of the mayor (Bürgermeister) or the lord mayor (Oberbürgermeister), as the case may be, or the collective form of the commune management board (an executive committee) known as the magistrate $^{28}$. The actual form depends on the locally binding model of selfgovernment, i.e. North German, South German, the magistrate or the mayor $^{29}$. According to R. Kusiak-Winter, the above mentioned division is currently of no significance due to the reforms conducted in the 1990s when a wide-ranging harmonization of the legal solutions, in particular, with regard to the federal states, took place. As a result of the reform, the differences have narrowed down to the length of the mayor's term in office, the removal or dismissal of the mayor by the council and the division of competencies between the council and the mayor ${ }^{30}$.

Both in Poland and Germany, the commune plays its fundamental roles - being close to the citizen, it connects and integrates him with the country, provides for autonomy, guarantees safety and the sense of belonging to the community, ensures a better understanding and appreciation of the needs and problems of local residents. Furthermore, it is best positioned to utilise its potential of adequate and quick response ${ }^{31}$. What influences/shapes/defines the key role of the commune as a subject/entity charged with public tasks is the scope of these public tasks.

\footnotetext{
${ }^{24}$ Miemiec (n 23) 53.

${ }^{25}$ Korczak (n 22) 276.

26 Lidia Zacharko (ed), Model ustroju samorzadu gminnego $w$ wybranych krajach europejskich (Difin 2013) 94.

${ }^{27}$ Joanna Jagoda, 'Organizacja samorządu terytorialnego w Niemczech' in Marta Woźniak, Joanna Ryszka (eds), 'Prawno administracyjne regulacje samorządności i zarządzania państwem w Unii Europejskiej' (Wydawnictwo Uniwersytetu Opolskiego 2006) 210.

${ }^{28}$ Zacharko (n 27) 93.

${ }^{29}$ Miemiec (n 23) 53, see: Korczak (n 22) 282.

${ }^{30}$ Kusiak-Winter (n 11) 104.

31 ibid 10.
} 


\section{Carrying Out Public Tasks the Communes in Poland and GERMANY}

Fulfilling the public tasks by the units of territorial self-governments both in Poland and Germany is connected with the principle of subsidiarity, in accordance to which decisions should be taken at the level that is closest to the residents of a territorial community if such a decision is expected to be most successful at this level ${ }^{32}$.

The German model of public tasks performed by the community is not uniform. It differs from Land to Land between a monistic concept and a dualistic one. In addition to a range of tasks fulfilled in their selfgovernment capacity, the communes carry out either delegated (mandated) or obligatory tasks. The former if they operate under the dualistic model and the latter if they follow the monistic concept, in which case conformity with the guidelines is required ${ }^{33}$. The delegated (mandated) tasks are transferred to the communes by the state on the basis of national legislation and executed subject to the guidelines. In accordance with the monistic model, the guidelines follow from the laws which provide for the transfer of the tasks. Such guidelines must however be general. They should not step into the executive sphere in any exaggerated manner, especially as regards personnel, devices or means selected on their own ${ }^{34}$.

Irrespective of the above classification, the tasks are divided into voluntary and obligatory. They are carried out by each commune autonomously on its own responsibility ${ }^{35}$. As regards voluntary tasks, the commune uses the presumption of competence and makes an autonomous decision of whether or not it wishes to accept them and as to how it will perform them. The commune performs all tasks explicitly delegated to it in accordance with the legislation. It may, however, apply the presumption of competence to independently determine and perform new public tasks ${ }^{36}$. There are, however, certain conditions attached as new tasks are decided. They must fall within the category of local community issues and they must not be reserved for the competences of other public authorities. What is also important is that the commune must be able to secure adequate means and measures to ensure their successful completion ${ }^{37}$. The implementation of voluntary tasks is always regulated in the spirit of a local legal act that is passed on the basis of the general authority granted by virtue of the commune ordinance, but when a local legal act interferes in the sphere of

\footnotetext{
${ }^{32}$ Dolnicki (n 16) 355.

${ }^{33}$ Miemiec (n 23) 79.

${ }^{34}$ ibid 80 .

35 Eugeniusz Ruśkowski, Bogdan Dolnicki (eds), 'Władza i finanse lokalne w Polsce i krajach ościennych', (Oficyna Wydawnicza Branta 2007) 56.

${ }^{36}$ Ewa Olejniczak-Szałowska, 'Zadania własne i zlecone samorządu terytorialnego' (2000) 12 Samorząd Terytorialny 12-13.

37 Carlo Panara, Michael R. Varney (eds), Local Government in Europe: The 'Fourth. Level' in the EU Multi-Layered system of governance (Routledge 2013) 89.
} 
the principal constitutional rights of the recipients of such a task, special authorization is required ${ }^{38}$.

The obligatory tasks of self-government performed by the commune on the basis of the legislation include: welfare, primary education, youth services, road construction and maintenance, water supply, sewage and wastewater treatment and collection, establishing and maintaining cemeteries and firefighting and fire protection ${ }^{39}$. As part of its voluntary tasks the commune may establish, operate and maintain orphanages, nursing homes, hospitals, sports and leisure facilities, libraries or public corporations. The commune is also commissioned to execute certain tasks assigned to the state administration, which i.a. comprise civil first response organizations, issuing passports, supervising health care, building control, industrial inspection and registration of vital records ${ }^{40}$. As noted by $\mathrm{J}$. Korczak, in case of any obstacles preventing the fulfilment of a task by the commune e.g. such as a financial predicament and/or staff shortages, the common practice is to enter into cooperation with other communes and transfer the performance of such a task onto the self-government supra municipal institutions (e.g. vital records registration tasks) ${ }^{41}$.

The commune also engages in elective tasks and makes an independent decision on taking up a particular task. As indicated by A. Błaś, such tasks are the most complete expression of the commune's autonomy, not to be confused with arbitrariness. In resolving the question of whether to proceed or not with a particular voluntary task, communes are required to test each case for compliance with the constitutionally protected values and norms ${ }^{42}$. It is worth paying attention to the issue of optional tasks - if the commune fails to fulfil an optional task, it has to be accomplished by the county.

In the Constitution of the Republic of Poland, Polish legislators use the classic division of tasks allocated to the territorial self-government into self-government's own tasks and mandated tasks. In determining the scope of commune tasks, the Commune Self-government Act provides for a general treatment on the presumption that the commune's ownership of all public cases of any local significance must not be reserved in favour of other entities $^{43}$. The purpose of the commune's own tasks is to meet the collective needs of the community. On the other hand, the commune fulfils some tasks which belong to the state administration and are commissioned to the commune for execution. Commissioned tasks must result from the justified needs of the state. Both own and mandated tasks have their origin

\footnotetext{
${ }^{38}$ Stasikowski (n 8) 108.

${ }^{39}$ Marek Stefaniuk, Jan Szreniawski, 'Główne reformy administracyjne w Polsce w latach 1989-2009' in Jerzy Supernat (ed) Między tradycja a przyszłościa $w$ nauce prawa administracyjnego. Ksiega jubileuszowa dedykowana profesorowi Janowi Bociowi (Wydawnictwo Uniwersytetu Wrocławskiego 2009) 146.

${ }^{40}$ Korczak (n 22) 287.

41 ibid 288.

42 Adam Błaś 'Zadania administracji publicznej' in Adam Błaś, Jan Boć, Jan Jeżewski (eds), Administracja publiczna (Kolonia Limited 2004) 140.

${ }^{43}$ Dolnicki (n 16) 78.
} 
in the relevant piece of legislative provision ${ }^{44}$. The commune's own tasks include meeting the community needs concerning i.a. the issues of local road transport, the municipal water distribution network and the sanitary drainage network, welfare, public education, culture, healthcare, libraries, family support services, the commune cemeteries, public order, pro-family politics, commune promotional activities, cooperation with nongovernmental organizations, law and order. The commune's own tasks are divided into two categories: obligatory and voluntary ${ }^{45}$.

All tasks commissioned to the commune are those which by principle belong to the state administration and are transferred to be executed by territorial self-governments ${ }^{46}$. This can be done either, by statutes where a law exists that instructs the commune to accept a task, or by an agreement whereby the commune's body may, at its discretion, enter into an agreement with the state administration. In all cases, however, there is a condition; namely the guarantee given by the state administration that adequate funding will be available to successfully complete the task ${ }^{47}$.

\section{CONCLUSION}

To conclude; the situation of the commune as the basic unit of territorial self-government is similar both in Poland and Germany. It is clearly visible that Polish legislators derived from German patterns while positioning of the commune in the system. The similarity appears especially in the fact that the commune is in both countries a council - a representative body directly elected by the citizens. Both in Poland and the majority of the federal states, the commune's executive body is a monocratic body appointed by the process of direct election ${ }^{48}$.

In both cases the territorial self-government is comprised of the community inhabiting a particular area and organized as a territorial selfgovernment association empowered by the state as a legal person in order to carry out its activities ${ }^{49}$. It executes certain tasks of the state by deployment (decentralization).

Both in Poland and Germany, communes fulfil two kinds of activities - own (obligatory) and delegated. In Poland, the qualifying of the activity as own or delegated is conducted on the basis of the analysis of

\footnotetext{
44 Michał Kulesza, Dawid Sześciło, 'Local Government in Poland' in Angel-Manuel Moreno (ed), Local government in the Member States of the European Union: a comparative legal perspective (National Institute of Public Administration 2012) 490.

${ }^{45}$ Marcin Miemiec 'Działalność gospodarcza gmin w Republice Federalnej Niemiec', in Adam Błaś, Konrad Nowacki (eds) Wspótczesne europejskie problemy prawa administracyjnego $i$ administracji publicznej. W 35. rocznice utworzenia Instytutu Nauk Administracyjnych Uniwersytetu Wrocławskiego (Wydawnictwo Uniwersytetu Wrocławskiego 2005) 294.

${ }^{46}$ Kusiak-Winter (n 11) 118.

${ }^{47}$ Dolnicki (n 16) 358.

${ }^{48}$ Jagoda (n 28) 219.

49 Zygmunt Niewiadomski, Samorzad terytorialny $w$ Europie Zachodniej. Podstawowe założenia i modele (Fundacja Rozwoju Demokracji Lokalnej 1990) 11.
} 
every task in reference to the material law. It is similar in Germany, where the ordered activities conducted by the commune must result from the acts. The commune's obligatory tasks in regard to Polish and German regulations are realized on their own behalf and as the own responsibility of the commune; however their financing is completed from the commune's budget. In both countries, the further division of own activities into obligatory and voluntary was applied, however in neither case was the closed catalogue of commune own activities indicated, making the activities dependant on the needs of the particular society. In spite of this the Polish legislator, in article 7 of commune territorial self-government, indicates the catalogue of commune's own activities, but it is not comprehensive. The German legislator made the inclusion of the particular task into the group of local society issues dependant on the specific conditions of every commune. The nature of optional activities of communes is similar in both countries (it includes i.a. the issues concerning theatres, museums, building sport facilities) and is dependent on the financial condition of commune ${ }^{50}$.

In Poland, the delegated tasks are those public activities fulfilled by communes imposed by law and resulting from the justified needs of the country. The similar solution is applied by the German legislator. Both Polish and German communes have the determined scope of independence in fulfilling the delegated activity - in both cases, the ordering party transfers the appropriate financial means for the commune being necessary to realize the particular activity.

The main areas of public tasks of Polish and German communes include shaping the structure, asset management, tax enforcement and collection, basic public education, health care and welfare, local public transportation, cultural and sports facilities, planning and urban planning. On the basis of aforementioned statement, it is clearly visible that Polish and German communes, as units being the closest from the territorial government for the society, fulfill the most important public activities and despite some differences resulting from the state's regulations, they have really much in common.

\section{References}

Błaś Adam, 'Zadania administracji publicznej', in Błaś Adam, Boć Jan, Jeżewski Jan (eds) 'Administracja publiczna' (Kolonia Limited 2004)

Boć Jan, Prawo administracyjne (Kolonia Limited 2010)

Dolnicki Bogdan, Samorzad terytorialny (Wolters Kluwer SA 2016)

Izdebski Hubert, Samorzad terytorialny. Podstawy ustroju i działalności (LexisNexis 2014)

Jagoda Joanna, 'Organizacja samorządu terytorialnego w Niemczech' in Woźniak Marta, Ryszka Joanna (eds), 'Prawnoadministracyjne regulacje samorządności i zarządzania państwem w Unii Europejskiej' (Wydawnictwo Uniwersytetu Opolskiego 2006)

${ }^{50}$ Kusiak-Winter (n 11) 121-132. 
Jeżewski Jan (eds), 'Samorząd terytorialny i administracja w wybranych krajach. Gmina w państwach Europy Zachodniej' (Wydawnictwo Uniwersytetu Wrocławskiego 1999)

Kisiel Wiesław, 'Wstęp' in Chmielnicki Paweł (eds), 'Ustawa o samorządzie gminnym. Komentarz' (LexisNexis 2010)

Korczak Jerzy, Lisowski Piotr, Ostapski Adam, Ustrój samorządu terytorialnego. Materiały dydaktyczne (Prawnicza i Ekonomiczna Biblioteka Cyfrowa 2015)

Kulesza Michał, Sześciło Dawid, 'Local Government in Poland' in Moreno A. (eds), 'Local government in the Member States of the European Union: a comparative legal perspective' (National Institute of Public Administration 2012)

Kusiak Renata, 'Pozycja gminy w strukturze państwa polskiego i niemieckiego', Acta Universitatis Wratislaviensis No 1900, Prawo CCLIII

Kusiak-Winter Renata, Wspótpraca transgraniczna gmin Polski i Niemiec. Studium Administracyjnoprawne (Prawnicza i Ekonomiczna Biblioteka Cyfrowa 2011)

Leoński Zbigniew, Samorząd terytorialny w RP (C.H. Beck 2010)

Machalski Paweł, Europa samorzadna. Samorzad terytorialny w wybranych państwach Unii Europejskiej (Wydawnictwo Adam Marszałek 2015)

Miemiec Marcin, 'Działalność gospodarcza gmin w Republice Federalnej Niemiec' in Błaś Adam, Nowacki Konrad (eds) 'Współczesne europejskie problemy prawa administracyjnego i administracji publicznej. W 35. rocznicę utworzenia Instytutu Nauk Administracyjnych Uniwersytetu Wrocławskiego', (Wydawnictwo Uniwersytetu Wrocławskiego 2005)

Miemiec Marcin, Gmina w systemie administracji publicznej Republiki Federalnej Niemiec, (Kolonia Limited 2007)

Niewiadomski Zygmunt, 'Kierunki rozwoju samorządu terytorialnego' 1991 (1-2) Samorząd Terytorialny

Niewiadomski Zygmunt, Samorzad terytorialny w Europie Zachodniej. Podstawowe założenia i modele (Fundacja Rozwoju Demokracji Lokalnej 1990)

Olejniczak-Szałowska Ewa, 'Zadania własne i zlecone samorządu terytorialnego', 2000 (12) Samorząd Terytorialny

Panara Carlo, Varney Michael R. (eds), 'Local Government in Europe: The 'Fourth. Level' in the EU Multi-Layered system of governance' (Routledge 2013)

Ruśkowski Eugeniusz, Dolnicki Bogdan (eds), Władza i finanse lokalne w Polsce i krajach ościennych (Oficyna Wydawnicza Branta 2007)

Stasikowski Rafał, Gwarancje samorzadności gminnej w systemie prawnym Republiki Federalnej Niemiec $i$ Rzeczypospolitej Polskiej (Oficyna Wydawnicza Branta 2005)

Stefaniuk Marek, Szreniawski Jan, 'Główne reformy administracyjne w Polsce w latach 1989-2009' in 'Między tradycją a przyszłością w nauce prawa administracyjnego. Księga jubileuszowa dedykowana profesorowi Janowi Bociowi' (eds) Supernat Jerzy (Wydawnictwo Uniwersytetu Wrocławskiego 2009)

Winczorek Piotr, Komentarz do Konstytucji Rzeczypospolitej Polskiej z dnia 2 kwietnia 1997 r. (Liber 2000) 
Woźniak Marta, Ryszka Jan (eds), 'Prawno administracyjne regulacje samorządności i zarządzania państwem w Unii Europejskiej' (Wydawnictwo Uniwersytetu Opolskiego 2006)

Zacharko Lidia (eds), 'Model ustroju samorządu gminnego w wybranych krajach europejskich' (Difin 2013) 